\title{
Public Diplomacy and the International Paralympic Committee: Reconciling the Roles of Disability Advocate and Sports Regulator
}

Aaron Beacom, University of St Mark and St John

Ian Brittain, Coventry University

\begin{abstract}
Whilst the link between international diplomacy and the Olympic movement has been the subject of extensive academic and journalistic enquiry, the experience of diplomatic discourse relating to the relatively youthful Paralympic movement has received little attention. It occurs not just in the context of state diplomacy, where for example the Paralympic Games may provide a conduit for the pursuit of specific policy objectives, but also in relation to the engagement of the International Paralympic Committee [IPC] as an evolving non-state actor in the diplomatic process. The idea of the IPC as an advocacy body engaged through public diplomacy in promoting disability rights needs exploration as an element of the contemporary politics of disability. This analysis considers the relationship between the activities of the IPC and wider lobbying by disabled people's organisations as a means of leveraging change in domestic and international policy toward disability. In relation to the global development agenda, it also assesses IPC responses to the gulf in resourcing for para-sport - as well as related health and education provision - between high- and low-resource regions. It considers the response of the organisation from the perspective of public diplomacy and locates that response within the wider diplomacy of development.
\end{abstract}


The emergence of the Paralympic Games is a relatively recent - post-Second World War phenomenon. Given its origins in efforts to engage with sport as a tool to facilitate the rehabilitation of disabled war combatants - beginning with the 1948 Stoke Mandeville Games - significant historical links exist between the Games and wider geo-political events. The relatively recent arrival of the Paralympic Games, its smaller scale, and political sensitivity towards disability has meant that they do not feature as prominently in international diplomacy as have the Olympic Games. There are, however, important caveats: namely, since they follow the Olympic Games, "overspill” from diplomatic tensions relating to the Olympic Games has affected the Paralympic Games. In addition, the rapid - although inconsistent - increase in the scale of the event - 328 athletes from 21 countries competing across nine sports in 1960, increasing to 4,237 athletes from 164 countries competing across 20 sports in $2012^{1}$ - and its links to the wider human rights agenda are increasingly drawing the Paralympic Games into diplomatic discourse.

The International Paralympic Committee [IPC] is primarily concerned with the development of elite international sport for people with disabilities. Nevertheless, to establish itself as an international actor and advocate for the rights of people with disabilities, moves towards patterns of interest representation that suggest its engagement in the diplomatic process is broadly-defined. The final part of the Paralympic Vision highlights it:

to inspire and excite the world: the external result is our contribution to a better world for all people with a disability. To achieve this, relations with external organisations and the promotion of the Paralympic movement as a whole are of prime importance. ${ }^{2}$

Promoting the rights of people with disabilities in resource-poor regions is critical to the longer-term development of Paralympic sport by countries within these regions. It in turn is 
central to developing the Paralympics as a global brand. The current limited reach of Paralympic sport presents a continuing challenge for the movement. In 2012, 20 percent of countries represented in the Olympics did not field a single athlete at the Paralympics, whilst many fielded only one athlete. In this sense, the governance and development of Paralympic sport entwine with wider concerns of disability advocacy.

Contending arguments as to what constitutes diplomacy have long formed part of the wider body of literature on international relations. ${ }^{3}$ Changing conceptualisations of diplomacy can help develop an appreciation of Olympic and Paralympic sport as increasingly prominent aspects of contemporary international relations. Yet, there has until recently been limited scholarly work that engaged in a systematic analysis of international sport from the perspective of studies in diplomacy. This scholarly lacuna prompted the formation in 2011 of the Diplomacy and International Sport Research group by Stuart Murray, Geoffrey Pigman, and Simon Rofe. ${ }^{4}$ Their subsequent work develop key themes in the debate. In particular, they call for more effective engagement between theorists and practitioners in sport and diplomacy; the implications of the exponential rise in person-to-person exchanges - virtual and personal through the medium of international sports events on the global development of public diplomacy; and the significance of football clubs with global reach on the public diplomacy domain. $^{5}$

The body of literature focusing specifically on diplomacy as it relates to the Olympic Games can provide valuable material when seeking to understand the changing dynamics of the sport-diplomacy relationship. Explored by social and political historians concerned with the use of sport as a conduit for state diplomacy, pre-occupations with the state and bi-polar tensions of the Cold War found their echoes in the Olympic boycotts of the 1980s. ${ }^{6}$ Writers from a range of 
disciplines adopting more pluralist interpretations of international relations and diplomacy have articulated the commercialisation of Olympic sport and the development of global interests relating to the Games, particularly in the post-Cold War period. ${ }^{7}$ They focus for example on developing relations between the International Olympic Committee [IOC] and the United Nations [UN] and the capacity of multi-national corporations with a stake in the Games to influence events on the ground.

With sport in diplomacy continuing to evolve as an aspect of wider international relations, more recent conceptualisations of diplomacy throw light on these changes, chiefly in the context of increasing efforts by organisations constituting the Paralympic movement to influence wider policy processes. They include, for example, insights provided through engagement with Brian Hocking's concept of "multi-stakeholder diplomacy", predicated on the idea of the diplomatic process being increasingly concerned with the creation of networks embracing a range of state and non-state actors focusing on the "management of issues demanding the application of recourses in which no single participant possesses a monopoly". 8 More recently, Hocking, Jan Melissen, Shaun Riordan, and Paul Sharp's conceptualisation of "integrative diplomacy" focused on the expansion of actors beyond traditional nongovernmental organisation [NGOs] - and organisations constituting the state - to encapsulate different forms of civil society groups. ${ }^{9}$ In relation to the Paralympic Games, engagement of disability and welfare organisations, which increasingly use the platform of the Games to advocate for the promotion of disability rights nationally - for example in London 2012 - and globally - in Beijing 2008 - would appear to bear this out. Use of new media platforms by such groups, like the charity, Scope, which provides detailed guidelines concerning their effective use as part of campaigning strategies, ${ }^{10}$ highlights the significance of such technological 
developments in promoting these novel forms of diplomatic activity. ${ }^{11}$ In discussing networks associated with public diplomacy, Hocking comments on the role of new media forms in the generation of "multi-directional flows" of information that have replaced the hierarchical flows traditionally associated with diplomacy. Such information can be generated by a range actors who as "producers" rather than "consumers" of the diplomatic message, whilst not necessarily setting out primarily to change policy, will often have the wider aim of influencing "elite attitudes and policy choices". ${ }^{12}$ The IPC has focused increasingly on social media platforms to promote their own narratives of inclusion and empowerment through the Games. Social media, it seems, enabled the Paralympic Movement to engage new audiences and broaden the reach and appeal of "the Games and the Movement". ${ }^{13}$ Athlete engagement, for example, provided the opportunity to provide an athlete's perspective on a range of Paralympic experiences and open up a new dimension of the Games to audiences. Conceptualisations of diplomacy in such fluid, integrative forms also helps to articulate ideas of the blurring of boundaries between domestic and international policy. They reflect for instance how the promotion of the disability agenda by countries hosting the Olympic and Paralympic Games become part of wider efforts to enhance their disability rights record as an aspect of their international profile in the run-up to and during the Games. ${ }^{14}$

The idea of public diplomacy is articulated variously, including attempts by organisations - primarily although not exclusively state-sponsored - to influence directly opinions of "publics" internationally, identity creation and image projection as an instrument to "understand cultures, attitudes and behaviour; build and manage relationships; and influence thoughts and mobilize actions to advance their interests and values" ${ }^{15}$ It is significant to this investigation since actors engage with the Paralympic Games as a route to refining the broader 
narrative concerning the relationship between the Games and the characteristics of the host nation. In relation to London 2012, written evidence by Nicholas Cull to the Foreign Affairs Select Committee on Foreign and Commonwealth Office [FCO] Public Diplomacy made particular reference to the prominence given to the Paralympic Games within the FCO 2012 plan. Cull contends,

There are many countries around the world in which differently-abled people do not have the opportunities they enjoy in Britain, and by increasing international exposure to the Paralympics emphasis on what people can do the FCO is performing a significant act of ethical leadership and associating the UK with some truly inspirational people. ${ }^{16}$

The House of Commons Foreign Affairs Select Committee concluded its enquiry into FCO public diplomacy relating to the Olympic and Paralympic Games and published its findings on 6 February 2011. Noteworthy, beyond Cull's commentary, was the limited reference to the Paralympic Games - as opposed to reference to the Olympic Games. Oral evidence given by Conrad Bird, head of Public Diplomacy at the FCO, in response to a question by MP David Watts concerned the use of the Paralympic Games to promote the image of Britain as an open and inclusive society. He drew attention to the engagement of Tanni-Grey Thompson, a Paralympic gold medallist, as an Olympic ambassador and her visit to Palestine. Bird suggested, "We felt that the Paralympics was a good opportunity to demonstrate British attitudes toward disability. We felt that could be an example of promoting the British way of doing things and our values". ${ }^{17}$ Beyond state interests in these processes, the idea of public diplomacy is helpful in understanding the behaviour of the IPC as it seeks, in its formative years, to develop its engagement as a global disability rights advocate. 
Regarding the Paralympic movement more generally, its youthfulness in comparison to the Olympic movement is the most significant issue that characterises its engagement with the diplomatic process. Initiated in 1896, the Olympic movement has evolved over 120 years, shaped by fundamental shifts in international relations and the technological developments that in part fuelled those shifts. In contrast, the Cold War had ended by the time that the IPC formed in 1989. As organisations characteristic of an emerging international order, and with their focus on issues relating to the wider human rights agenda alongside the promotion of new forms of elite adaptive sports, the constituent organisations of the Paralympic movement would be attempting to find their voice in a very different diplomatic environment. Table 1 places some historical perspective on this process.

Table 1 Olympic and Paralympic diplomacy: structure and agency

\begin{tabular}{|c|c|c|c|}
\hline & $\begin{array}{l}\text { Diplomacy - } \\
\text { conceptual debates } \\
\text { and structural } \\
\text { developments }\end{array}$ & $\begin{array}{l}\text { Diplomacy and the } \\
\text { Olympic movement }\end{array}$ & $\begin{array}{l}\text { Diplomacy and the } \\
\text { Paralympic } \\
\text { movement }\end{array}$ \\
\hline Pre-war & $\begin{array}{l}\text { Closed diplomacy - } \\
\text { Gentlemen, amateurs } \\
\text { and imperialists }\end{array}$ & $\begin{array}{l}\text { Early Games as } \\
\text { inherently diplomatic } \\
\text { (consensus building } \\
\text { between elites on and } \\
\text { off the field of play) }\end{array}$ & \\
\hline Inter-war & $\begin{array}{l}\text { Open diplomacy - } \\
\text { democratisation as } \\
\text { reaction to failure }\end{array}$ & $\begin{array}{l}\text { IOC contact with } \\
\text { League of Nations - } \\
\text { new idealism }\end{array}$ & \\
\hline Cold-war & $\begin{array}{l}\text { 'New' diplomacy } \\
\text { (the } 1960 \text { Vienna } \\
\text { Convention on } \\
\text { diplomacy - the apex } \\
\text { of state diplomacy?) }\end{array}$ & $\begin{array}{l}\text { Olympic Boycotts as } \\
\text { instruments of state } \\
\text { diplomacy }\end{array}$ & \\
\hline Post-cold-war & $\begin{array}{l}\text { Multi-stakeholder } \\
\text { diplomacy - multi- } \\
\text { layered engagement } \\
\text { by diverse actors }\end{array}$ & $\begin{array}{l}\text { State, sub-state and } \\
\text { non-state engagement. } \\
\text { IOC } 2000 \\
\text { Commission - } \\
\text { response to moral } \\
\text { crisis } \\
\text { Cultural Olympiad as } \\
\text { Public Diplomacy }\end{array}$ & $\begin{array}{l}\text { Embryonic - gradual } \\
\text { engagement in } \\
\text { discourse relating to } \\
\text { human / disability } \\
\text { rights as an aspect of } \\
\text { international relations }\end{array}$ \\
\hline Post 9/11 & Re-defining 'soft & Mediation and new & Formalised advocacy \\
\hline
\end{tabular}




\begin{tabular}{|l|l|l|l|}
\hline & $\begin{array}{l}\text { power' as diplomacy } \\
\text { electronic media and } \\
\text { multi-directional } \\
\text { information flows re- } \\
\text { interpreting public } \\
\text { diplomacy }\end{array}$ & $\begin{array}{l}\text { security realities } \\
\text { Commercial } \\
\text { diplomacy and the } \\
\text { Games - blurring } \\
\text { national and } \\
\text { international } \\
\text { boundaries }\end{array}$ & $\begin{array}{l}\text { coalitions relating to } \\
\text { human rights } \\
\text { (national, } \\
\text { transnational and } \\
\text { global) }\end{array}$ \\
$\begin{array}{l}\text { Constructivism as } \\
\text { practical response to } \\
\text { conflicting world- } \\
\text { views. }\end{array}$ & $\begin{array}{l}\text { Olympic movement as } \\
\text { actor in development } \\
\text { diplomacy } \\
\text { Paralympic movement } \\
\text { and public diplomacy } \\
\text { - projecting images of } \\
\text { a tolerant society. }\end{array}$ \\
& $\begin{array}{l}\text { Cosmopolitanism and } \\
\text { image development - } \\
\text { public diplomacy and } \\
\text { the London 2012 bid } \\
\text { aralympic movement } \\
\text { as actor in } \\
\text { development } \\
\text { diplomacy }\end{array}$ \\
& $\begin{array}{l}\text { Paralympic movement } \\
\text { as inherently } \\
\text { diplomatic. } \\
\text { Challenging the world } \\
\text { view on disability? }\end{array}$ \\
\hline
\end{tabular}

The IPC was then seeking to establish itself in a rapidly evolving diplomatic environment characterised by a more complex configuration of actors and issues.

As an expanding international sporting event closely linked to the Olympic Games and engaged directly in advocating disability rights, the international debate concerning the politics of disability increasingly draws in the Paralympic Games. Complicating this process is the maturing of the Games that, according to Peter Horton and Kristine Toohey, has led to loss of their sporting innocence. ${ }^{18}$ They cite comments that as Paralympic sport has matured, it has appropriated some of the most desirable aspects of mainstream Olympic sport. ${ }^{19}$ At the same time, however, "there were the less desirable signs of maturation - evidence of banned drug use, increased security precautions, and the shake out of less glamorous sports in favour of the 
flashy ones that sell well". As the Paralympic Games have worked to enhance their profile, they have increased their political currency. States, most notably China, have invested heavily in improving their performance in the medals tally. The twin perceptions that improved performance will promote international prestige and states supporting disability in such a visible way will see a more positive light shine on them regarding their social and cultural policies is implicit in such increased investment. ${ }^{20}$ At the same time, the IPC and other disability sports actors - as well as international disabled person's organisations [DPOs] generally - are availing themselves of the opportunity to promote their own interests in an environment in which states vie with one another to enhance their reputation regarding civil liberty and inclusion. The rapid increase in the scale of the Paralympic Games over recent years and the increased media interest in the Games helps foster the view that the Paralympic Games have been "mainstreamed". It follows that the Paralympic Games will attract the attention of those organisations seeking to use international sport as a conduit for diplomatic discourse. A combination of the politicisation of disability and relationships between organisations representing non-disabled sport and sport for people with disabilities, however, has set a specific frame of reference for the development of the Paralympic movement and how such a movement moves into the wider political and diplomatic debate.

The idea that the Olympic Games can become a conduit for the pursuit of state foreign policy objectives is a consistent theme in literature on sport and international relations. The extent to which this policy-frame draws in the Paralympics is less clear. The proximity of the Paralympic Games to the Olympic Games, particularly since 1988, has resulted in a spill over of diplomatic activity. In relation to British diplomatic support, Olympic attachés are, for example, responsible for providing support for both the Olympic and Paralympic teams. As the 
scale of the Paralympic Games has increased, it has significantly amplified the responsibility of diplomatic and consular services in the build-up to the Games, a point readily acknowledged by operatives working in the field.

The potential of the Paralympic Games to provide a conduit for traditional state diplomacy is noteworthy on a number of levels. At the most fundamental, the capacity of the Paralympics to provide a platform for senior politicians and heads of state to enhance their visibility against the backdrop of such an ostensibly positive activity likely to engender public empathy as sport and disability should not be under-rated. It is noteworthy that at a time of increasing tension between Western Powers and Iran, the Iranian president, Mahmoud Ahmadinejad, took the opportunity of the opening ceremony of the 2008 Paralympics in Beijing to travel to China and meet a number of senior diplomatic and government figures. The official press commented that the Iranian entourage included the foreign minister, Manuchehr Mottaki, the vice-president, Esfandiar Rahim Mashaii, the Physical Education Organisation head, Mohammad Aliabadi, and a senior advisor to the government, Mojtaba Samareh Hashemi. This high profile visit contributed to attempts to develop a more progressive perspective of the regime regarding the rights of minority groups. Coinciding with the visit, the official Iranian news agency, IRNA, issued a press release noting that Iranian female athletes with physical disabilities would participate for the first time in the Paralympic Games, competing in track and field, shooting, and table tennis. Prior to the visit, an Iranian Foreign Ministry spokesman, Hassan Qashqavi, released a statement noting that Ahmadinejad's visit was "aimed at highlighting the great ability of the [Paralympic] athletes". ${ }^{21}$ In the statement, he referred to Paralympians as "suffering" from disability, reflecting a traditional medical interpretation of disability that contrasted with IPC attempts to re-focus away from 
problematising disability and toward a greater emphasis on the ability of athletes. At the same time, he commented that the visit would provide the opportunity for senior officials of the two countries to hold talks on "issues of mutual interest". 22

Attempts to enhance international perceptions of a state through hosting Paralympic events are evident when reading accounts of journalists, spectators, and participants who have travelled abroad for events. This certainly formed the backdrop for the 2008 Paralympics in Beijing. Prior to the Beijing Games, there was intense speculation concerning how the Chinese government would respond to the challenge of hosting an event for disabled athletes given the negative publicity China had received in the past regarding disability rights. Prior to the Games, the Chinese government engaged in a number of high profile initiatives that helped to enhance the perception of respect for disability rights within Chinese society. It included China signing the UN Convention on the Rights of Persons with Disabilities in March $2007 .{ }^{23}$ Other national initiatives encompassed the heightened profile given to the long-standing national Help-theDisabled-Day, held in China on the third Sunday of every May, in the form of widely publicised free medical check-ups, job fairs, and a series of consultations on inclusive building design. $^{24}$

Beyond the Paralympic Games, the hosting of world championships in a range of parasports has provided the opportunity for municipal authorities and national governments to develop their human rights profile in the international arena. The Paralympic shooting world championships held in Zagreb, Croatia in July 2010, for example, was a significant event for the host country, still engaged in developing its international profile in the wake of the Balkan conflict of the 1990s. Organised by the Croatian National Paralympic Committee [NPC], it was the first world championship in a sport for athletes with a disability held in the country. ${ }^{25}$ It is 
noteworthy that the Croatian prime minister attended the event and, along with the mayor of Zagreb and the IPC president, was engaged in the ceremonies and welcoming speeches that accompanied the competition.

Beyond providing a forum for developing the profile of senior politicians domestically and internationally, the Paralympics and their forerunner, the Stoke Mandeville Games, merge from time to time with wider foreign policy developments. Most notably, the unfolding debate about how to respond to sporting links with South Africa caught up with the Paralympic movement. ${ }^{26}$ Whilst some commentators argued that disability was a levelling experience and that disability sport should not affect international politics - hence, the admittance of the South African team to the 1968 Paralympic Games - the Netherlands government succeeded in getting the South African team excluded from the 1980 Games. $^{27}$

In the context of public policy, interest groups like those concerning disability rights groups who may attract the support of sympathetic Paralympic athletes have the capacity to use the Games to express their opposition to particular policy developments perceived to have a negative effect on the quality of life of people with disabilities. Of particular note was the concerted campaign to highlight the impact of proposed cuts by the British government to the Disability Living Allowance in advance of the Paralympic Games of $2012 .{ }^{28}$ In this case, the opposition did not have the desired affect since fully implementing the cuts still took place in April 2013. Alan Roulstone, professor of Applied Social Sciences (Disability Policy) at Leeds University, wrote on the policy press blog:

The most difficult aspect of the Paralympics for many disabled people has been the bizarre juxtaposition of seeing great sporting achievements (rightly) being applauded and 
poster girl/boy images of photogenic disabled people alongside arguably the most aggressive and top-down reform of welfare since the Poor Law. ${ }^{29}$

In this sense then, the cuts and their portrayal in the British media had a detrimental effect upon the desired Paralympic legacy espoused by the British government in advance of the Games.

Significant in the context of multi-stakeholder diplomacy, the convergence of state and non-state interests is evident at a number of levels. Symbolically, the ceremony to launch the new Paralympic logo for the Sochi 2014 Paralympic Games drew together the IPC president, Philip Craven, the Russian deputy prime minister, Aleksandr Zhukoc, and the UN special advisor on Sport for Development and Peace, Wilfried Lemke, along with a range of senior sports officials and event organisers. ${ }^{30}$ Notwithstanding anxieties with the organisation of the 2014 Games, as well as lingering concerns over the human rights record of the Russian regime, there was a shared interest among stakeholders to ensure that the event was successful. In that sense, engagement with the diplomatic process formed an increasingly important part of discourse relating to the Games.

Beyond the parameters of activities of state actors - including extensive logistical support for teams provided by diplomatic and consular services - organisations that constitute the Paralympic movement have engaged as international advocacy bodies in relation to wider concerns with equity, inclusion, and the rights of people with disabilities. In this respect, links between the IOC, IPC, and the UN on international conventions for people with disabilities have a particular significance. ${ }^{31}$ The idea of the IPC as an advocacy body engaged diplomatically within international society to promote disability rights exists within the wider context of debate concerning the capacity of international sports NGOs to influence international affairs. The work of the Agitos Foundation as an attempt by part of the 
Paralympic movement to address systemic inequities in the distribution of resources required to support the development of Paralympic sport is part of that process since ultimately promotes the interests of a growing movement in a crowded global space. On 4 September 2012, the IPC launched the Agitos Foundation - taking its name from the Paralympic symbol, the Agitos - to fulfil its strategic goal in terms of development and education. Its aim was supporting the implementation of the 2006 UN Convention on the Rights of Persons with Disabilities and sustaining and delivering on the Paralympic movement's global objective of helping to create a more inclusive society.

As outlined above, the politicisation of disability rights and the perception that disability sports organisations, primarily the IPC that could effectively lobby to promote disability awareness, has drawn the IPC into international political discourse. This has not always worked in the interests of the sports organisations. For example, when China won the bid to host the 2008 Olympic and Paralympic Games, a number of influential stakeholders highlighted their concerns given China's poor record of accomplishment concerning disability rights. ${ }^{32}$ This initially included comments made by Tanni-Grey Thompson indicating anxieties about disability rights in China and suggesting the danger of using the Paralympics to mask underlying issues with their human rights record.

The staging of the 2008 Paralympic Games in Beijing provided the opportunity for a number of DPOs to monitor disability rights in an unprecedented way. The campaigning journal, Disability Now, despatched four individuals with disabilities to monitor the level and quality of provision for the disabled. This included Zara Todd, campaigns officer at Scope and the BBC's disability affairs correspondent. Todd reported that although volunteers were enthusiastic, adaptive measures did not generally appear to derive from consultation with 
people with disabilities. Todd suggested that whilst exposure to coverage of disability sport could help promote disability awareness, China was only beginning to find its way when it came to disability rights. At the same time, a Disability Now journalist reported his shock at the apparent lack of disability awareness within much of the population..$^{33}$ Other commentators reporting that three years before the Games a disabled person would be pointed out in the street tempered such a perspective. However, despite widely reported limitations, the Paralympics had resulted in people with disabilities in China "coming out of the shadows".

The engagement of the Paralympic movement generally, and the IPC more specifically, in the development process is in part driven by the imperative to expand and consolidate its role as a key actor in the arena of international relations. Despite ongoing challenges with governance and corruption, the IOC has existed for 119 years at the time of writing, establishing itself as a widely recognised actor in international relations, something reflected, for example, in the organisation gaining Observer status within the UN General Assembly in 2010 and its work with the UN Office of Sport for Development and Peace. ${ }^{34}$ In contrast, the IPC as an organisation in its formative years is still finding its place in the international arena. Diplomatic activity relating to the development process forms a particularly important part of this.

There are two significant inter-linked aspects to the international sport for development agenda and activities in relation to the efforts of the IPC. On one hand, the organisation has engaged in a number of disability sport and development initiatives in partnership with a range of stakeholders that illustrate efforts to enhance their profile as an international disability rights advocacy body. On the other, it has committed, most recently through the work of the Agitos Foundation, to support the expansion and development of para-sport internationally. 
Whilst the perception that the global South has less respect for disability rights is not necessarily based on empirical evidence, issues concerning disability rights common to a number of states across the global South can be identified. They relate to relatively low GDP, under-provision in basic health care, transport and communication problems, and political instability - leading to increased risk of conflict with corresponding disabling injuries. It is against this background that disability sports organisations, in particular the IPC, have become increasingly involved with sports-based interventions that attempt to ameliorate the problems flowing from poverty and social exclusion faced by people with a disability. Whilst such challenges are evident in many regional contexts, the focus here is on regions within the African continent.

Britain's Department for International Development [DFID] broadly defines social exclusion as a process by which certain groups are systematically disadvantaged because they face discrimination based on their ethnicity, race, religion, sexual orientation, caste, descent, gender, age, disability, HIV status, migrant status, or where they live. ${ }^{35}$ Discrimination occurs in public institutions, such as the legal system or education and health services, as well as social institutions like the household. DFID identifies social exclusion as a priority because it both causes poverty and impedes poverty reduction. Moreover, poverty reduction policies rarely reach socially excluded groups unless specifically designed to include them. Albrecht interprets the impact of exclusion, particularly with respect to disability:

A person's position in society affects the type and severity of physical disability one is likely to experience and more importantly the likelihood that he or she is likely to receive rehabilitation services. Indeed, the political economy of a community dictates what 
debilitating health conditions will be produced, how and under the circumstances they will be defined, and ultimately who will receive the services. ${ }^{36}$

Cameron Crawford sums it up by stating that for most, "the economics of disability determine what life at the side-lines is like". 37

Besides poverty and disease, one of the major sources of disability in a number of African states is armed conflict brought about by political instability in parts of the continent. One of the main impacts of armed conflicts is that there is a high level of disabilities caused by small arms and light weapons, including anti-personnel landmines. Youth, both as civilians and combatants, appear to be one of the most affected groups with this problem, and it is often the case that there are no adequate socio-economic services and opportunities in post-conflict environments to help deal with the many issues raised by conflict-induced disabilities. However, it is equally important not to overlook the issues for those who received their disabilities because of accidents or birth defects; otherwise, there would be a risk of marginalising further an already marginalised group. People, and particularly children, with disabilities do not have equal opportunities and equal access regarding most parts of life. Handicap International claims that this lack of access includes basic services - especially education and health - because of physical inaccessibility to buildings, lack of information in adapted formats like Braille, and discriminatory behaviour within society. ${ }^{38}$ In addition, people with disabilities tend to suffer disproportionately during and after conflict situations. They are often the most exposed to protection risks, including physical and sexual violence, exploitation, harassment, and discrimination, ${ }^{39}$ particularly females. UN research indicates that violence against children with disabilities occurs at annual rates at least 1.7 times greater than that for their non-disabled peers. ${ }^{40}$ Finally, they also lack options for making a living and, therefore, the 
opportunity to transcend out of poverty, which often means either remaining as financial burdens on their families or begging to make a living.

The international development community have struggled in their attempts to employ interventions that effectively responded to the challenges posed by combinations of poverty, social exclusion, and disempowerment frequently associated with the lived experience of people with disabilities in resource-poor regions. The emergence of sport-based interventions commonly referred to as sport for development and peace - formed part of attempts to adopt alternative approaches to the development process, the objective being to use sport as a conduit through which issues such as health education, gender equality, empowerment, conflict resolution, and community development could be addressed. ${ }^{41}$ Given the rapid expansion of sport for development and peace programmes as part of the international development agenda, it is not surprising to observe a growing number of related activities resourced by organisations that constitute the Paralympic movement. One example is the use of regional events such as the All African Games as conduits for promoting their disability rights advocacy role. Rather ambitious statements made by the president of the African Paralympic Committee after the Joint Planning Meeting in October 2010 for the tenth All African Games in September 2011 reflect the heightened expectations that such events can make an impact on the priorities of policy-makers and perceptions of wider society toward disability. ${ }^{42}$

The activities of the IPC as an advocacy organisation engaged in the promotion of disability rights is reflected in its engagement with a range of international development initiatives over the past decade. Table 2 outlines a small number and, notably, many have involved minimal investment of resources. 
TabIe 2 IPC Development Partnerships (IPC archived Press Releases, IPC Website)

\begin{tabular}{|c|c|c|}
\hline $\begin{array}{l}\text { IPC / } 15 \text { NPCs from } 4 \text { regions } \\
2008\end{array}$ & $\begin{array}{l}\text { Organizational Development } \\
\text { Initiative (ODI) }\end{array}$ & $\begin{array}{l}\text { 'Some results of the ODI to } \\
\text { date are: the NPC of Tanzania } \\
\text { has acquired a new office } \\
\text { from the National Sports } \\
\text { Commission, the NPC of } \\
\text { Morocco intensified its } \\
\text { relationship with Handicap } \\
\text { International, an IPC } \\
\text { Development Partner, by } \\
\text { working together to develop } \\
\text { their new strategic plan..' }\end{array}$ \\
\hline $\begin{array}{l}\text { IPC / UNESCO } \\
2008\end{array}$ & Partnership initiative & $\begin{array}{l}\text { To promote the Convention } \\
\text { Against Doping in Sport, } \\
\text { increase awareness about } \\
\text { persons with a disability in } \\
\text { formal education systems } \\
\text { through the IPC's Paralympic } \\
\text { School Day programme and } \\
\text { promote girls and women as } \\
\text { leaders within sport. }\end{array}$ \\
\hline $\begin{array}{l}\text { IPC / Southern Africa NPCs } \\
2011\end{array}$ & $\begin{array}{l}\text { Launch of IPC Regional } \\
\text { Development } \text { Camp in } \\
\text { Lusaka, Zambia }\end{array}$ & $\begin{array}{l}\text { 'The camp, which is } \\
\text { sponsored by the Norwegian } \\
\text { Olympic and Paralympic } \\
\text { Committee and Confederation } \\
\text { of Sports (NIF) and Charity } \\
\text { and Sport, runs from } 3-8 \\
\text { October. Its goals include } \\
\text { creating a unique atmosphere } \\
\text { to give NPCs the opportunity } \\
\text { to share knowledge'. }\end{array}$ \\
\hline $\begin{array}{l}\text { IPC in partnership with Ivory } \\
\text { Coast NPC } \\
\text { (2011) }\end{array}$ & $\begin{array}{llr}\text { Element } & \text { of } & \text { IPC } \\
\text { Organizational } & \text { Development } \\
\text { Initiative } & & \end{array}$ & $\begin{array}{l}\text { Workshops and practical } \\
\text { initiatives to strengthen Ivory } \\
\text { Coast NPC - both in terms of } \\
\text { its activity as disability rights } \\
\text { advocate and in terms of } \\
\text { talent identification and coach } \\
\text { development. }\end{array}$ \\
\hline $\begin{array}{l}\text { IPC / UK Sport partnership in } \\
\text { sport-for-development } \\
\text { (2011) }\end{array}$ & $\begin{array}{l}\text { Memorandum } \\
\text { Understanding }\end{array}$ & $\begin{array}{l}\text { 'to enhance the capability and } \\
\text { capacity of NPCs worldwide, } \\
\text { with particular focus on } \\
\text { region of East Africa and } \\
\text { Portuguese speaking nations } \\
\text { in preparation for Rio 2016, } \\
\text { as well as to model best } \\
\text { practice in the areas of } \\
\text { grassroots } \\
\text { development, talent pathways } \\
\text { for children and young people }\end{array}$ \\
\hline
\end{tabular}




\begin{tabular}{|c|c|c|}
\hline & & $\begin{array}{l}\text { with disabilities and } \\
\text { educational resources to } \\
\text { support coaching and teaching } \\
\text { of disability sport'. }\end{array}$ \\
\hline $\begin{array}{l}\text { IPC / Agitos Foundation } \\
2013\end{array}$ & $\begin{array}{lll}\text { Agitos } & \text { Foundation } & \text { Grant } \\
\text { Support Programme } & \end{array}$ & $\begin{array}{l}\text { Funding to support capacity } \\
\text { building of the NPC...'since } \\
\text { then, para-sport in Rwanda } \\
\text { has been developed in new, } \\
\text { and more remote, areas of the } \\
\text { country and across a broader } \\
\text { range of sports at a grassroots } \\
\text { level. There are also more } \\
\text { trained technical staff to bring } \\
\text { athletes through the system, } \\
\text { such as coaches, classifiers } \\
\text { and referees, as well as } \\
\text { partnerships with the } \\
\text { Rwandan Athletics Federation } \\
\text { and an increase in NPC } \\
\text { Membership' }\end{array}$ \\
\hline $\begin{array}{l}\text { IPC Academy / Agitos } \\
\text { Foundation } \\
2014\end{array}$ & $\begin{array}{lr}\text { Cohort of } & \text { representatives } \\
\text { from } 12 \text { countries at first joint } \\
\text { resourced } & \text { Organizational } \\
\text { Capacity } & \text { Programme } \\
\text { (delivered in } & \text { Bonn, } \\
\text { Germany). } & \end{array}$ & $\begin{array}{l}\text { '..delivered by the IPC } \\
\text { Academy and the Agitos } \\
\text { Foundation, the a four-day } \\
\text { programme is designed to } \\
\text { strengthen NPCs in the areas } \\
\text { of governance, management, } \\
\text { leadership and sport } \\
\text { promotion'. }\end{array}$ \\
\hline $\begin{array}{l}\text { IPC Academy / Agitos } \\
\text { Foundation } \\
2014\end{array}$ & 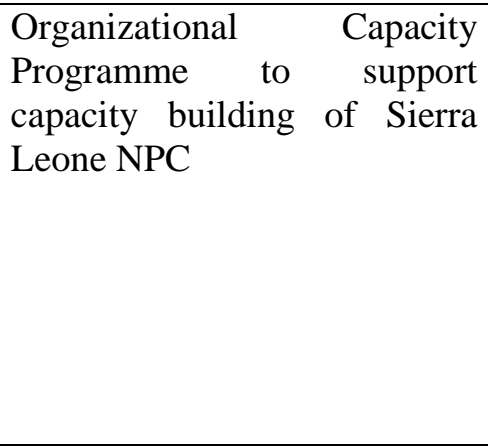 & $\begin{array}{l}\text { As above. Also, engagement } \\
\text { with state } \\
\text { representatives...'the Sport } \\
\text { Ministry [of Sierra Leone] } \\
\text { have restated their } \\
\text { commitment to para-sport in } \\
\text { Sierra Leone, after the NPC } \\
\text { were drafted in to a national } \\
\text { programme to help the } \\
\text { country recover from Ebola' }\end{array}$ \\
\hline $\begin{array}{l}\text { IPC / Agitos Foundation } \\
2014\end{array}$ & $\begin{array}{l}\text { Launch of second edition of } \\
\text { Grant Support Programme }\end{array}$ & $\begin{array}{l}28 \text { IPC } \text { member } \\
\text { organizations from around the } \\
\text { world will receive EUR } \\
650,000 \text { of funding through } \\
\text { the second edition of its } \\
\text { hugely successful Grant } \\
\text { Support Programme'. }\end{array}$ \\
\hline
\end{tabular}


The influence of the Paralympic movement as an advocacy organisation engaged in the promotion of disability rights is not limited to the IPC but also relates to the activities of NPCs - often in partnership with other stakeholders - and regional Paralympic committees. International Disability Day, co-ordinated by the UN Children's Emergency Fund [UNICEF], provides one such opportunity for NPCs with limited resources to engage in wider promotional work to enhance their profile. The Rwandan NPC, for instance, in partnership with UNICEF and Right to Play Rwanda, were able in 2011 to introduce boccia, goalball and sitting volleyball through inter-school competitions as part of International Disability Day celebrations. ${ }^{43}$ Notwithstanding the very limited scale of the programme and the embryonic state of the NPC, it provided the opportunity to develop links with the Ministry of Education, as well as wider social networking. Such examples highlight the relationship between the domestic and international political agenda in the context of disability sport. The shared interests of the Rwandan NPC and Right To Play - an international development organisation as advocates for disability rights and promoters of sport as a conduit for development creates a platform to engage with political interests, particularly in a situations where local infrastructure is resource-limited and under severe pressure as a result of regional political instability.

The most visible challenge faced by the IPC, significant in terms of its legitimacy as an international advocate for disability rights, is the gulf in resourcing for para-sport between high- and low-resource regions. This gulf creates an asymmetry between national teams, evident in levels of representation and podium success at para-sport events, and remains significant enough to challenge the very notion of the Paralympic movement as truly 
international in its reach. Appreciating the extent of this gulf is important before considering IPC efforts to address it and understanding why it is part of its engagement in the public diplomacy process. Tables 3, 4, and 5 highlight the extent of the challenge. Tables 3 and 4 demonstrate the clear dominance of the European nations particularly in the early development process of the summer and winter Paralympic Games - the latter heavily dependent upon access to expensive equipment and the right geographical and climatic conditions and where the dominance of European nations is even more evident than in the summer games.

Table 3 Nations participation at the summer Paralympic Games by Continental Association ${ }^{44}$

\begin{tabular}{|l|c|c|c|c|c|c|}
\hline Summer Games & Europe & Americas & Africa & Asia & Oceania & Total \\
\hline Rome 1960 & 16 & 2 & 1 & 1 & 1 & 21 \\
\hline Tokyo 1964 & 12 & 2 & 2 & 3 & 2 & 21 \\
\hline Tel Aviv 1968 & 16 & 4 & 3 & 3 & 2 & 28 \\
\hline Heidelberg 1972 & 23 & 7 & 5 & 5 & 2 & 42 \\
\hline Toronto 1976 & 19 & 10 & 3 & 5 & 3 & 40 \\
\hline Arnhem 1980 & 22 & 8 & 5 & 5 & 2 & 42 \\
\hline New York 1984 & 25 & 6 & 3 & 9 & 2 & 45 \\
\hline Stoke Mandeville 1984 & 19 & 10 & 3 & 6 & 3 & 41 \\
\hline Seoul 1988 & 27 & 11 & 5 & 16 & 2 & 61 \\
\hline Barcelona 1992 & 33 & 16 & 11 & 20 & 2 & 83 \\
\hline Atlanta 1996 & 41 & 18 & 16 & 25 & 3 & 103 \\
\hline Sydney 2000 & 41 & 20 & 20 & 34 & 7 & 122 \\
\hline Athens 2004 & 42 & 24 & 29 & 36 & 5 & 136 \\
\hline Beijing 2008 & 24 & 30 & 40 & 7 & 146 \\
\hline London 2012 & & 28 & 39 & 42 & 8 & 164 \\
\hline
\end{tabular}


Table 4 Nations participation at the winter Paralympic Games by Continental Association ${ }^{45}$

\begin{tabular}{|l|c|c|c|c|c|c|}
\hline Winter Games & Europe & Americas & Africa & Asia & Oceania & Total \\
\hline Örnsköldsvik 1976 & 12 & 2 & 1 & 1 & 0 & 16 \\
\hline Geilo 1980 & 12 & 2 & 1 & 1 & 2 & 18 \\
\hline Innsbruck 1984 & 16 & 2 & 0 & 1 & 2 & 21 \\
\hline Innsbruck 1988 & 17 & 2 & 0 & 1 & 2 & 22 \\
\hline Tignes 1992 & 18 & 2 & 0 & 2 & 2 & 24 \\
\hline Lillehammer 1994 & 24 & 2 & 0 & 3 & 2 & 31 \\
\hline Nagano 1998 & 22 & 2 & 1 & 4 & 2 & 31 \\
\hline Salt Lake 2002 & 25 & 3 & 1 & 5 & 2 & 36 \\
\hline Torino 2006 & 25 & 4 & 1 & 6 & 2 & 38 \\
\hline Vancouver 2010 & 30 & 5 & 1 & 6 & 2 & 44 \\
\hline Sochi 2014 & 30 & 6 & 0 & 7 & 2 & 45 \\
\hline
\end{tabular}

Table 5 Medal success at the London and Sochi Paralympic Games by Continental Association ${ }^{46}$

\begin{tabular}{|c|c|c|c|c|c|c|c|c|c|c|c|c|c|c|c|c|c|}
\hline & & & \multicolumn{3}{|c|}{ Africa } & \multicolumn{3}{|c|}{ Americas } & \multicolumn{3}{|c|}{ Asia } & \multicolumn{3}{|c|}{ Europe } & \multicolumn{3}{|c|}{ Oceania } \\
\hline \multirow{4}{*}{ 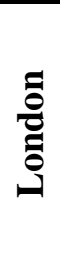 } & \multirow{4}{*}{ ำ } & \multirow{2}{*}{ Medals } & 3 & 3 & 3 & 7 & 7 & 7 & 12 & 10 & 10 & 22 & 26 & 26 & 3 & 3 & 3 \\
\hline & & & 8 & 6 & 8 & 6 & 0 & 5 & 7 & 6 & 3 & 3 & 1 & 6 & 9 & 0 & 4 \\
\hline & & Pts $(\%)$ & \multicolumn{3}{|c|}{$\begin{array}{l}224 \mathrm{pts} \\
(7.4 \%)\end{array}$} & \multicolumn{3}{|c|}{$\begin{array}{c}\text { 443pts } \\
(14.6 \%)\end{array}$} & \multicolumn{3}{|c|}{$\begin{array}{c}\text { 696pts } \\
(23.0 \%)^{*}\end{array}$} & \multicolumn{3}{|c|}{$\begin{array}{l}1457 \mathrm{pts} \\
(48.0 \%)\end{array}$} & \multicolumn{3}{|c|}{$\begin{array}{l}212 \mathrm{pts} \\
(7.0 \%)\end{array}$} \\
\hline & & Countries & \multicolumn{3}{|c|}{10} & \multicolumn{3}{|c|}{10} & \multicolumn{3}{|c|}{16} & \multicolumn{3}{|c|}{36} & \multicolumn{3}{|c|}{3} \\
\hline \multirow{3}{*}{ : } & \multirow{3}{*}{ ষ্ণ } & Medals & 0 & 0 & 0 & 9 & 9 & $\begin{array}{l}1 \\
6\end{array}$ & 3 & 1 & 2 & 60 & 61 & 52 & 0 & 1 & 2 \\
\hline & & Pts $(\%)$ & \multicolumn{3}{|c|}{0 pts $(0 \%)$} & \multicolumn{3}{|c|}{$\begin{array}{c}\text { 61pts } \\
(14.1 \%)\end{array}$} & \multicolumn{3}{|c|}{13 pts $(3.0 \%)$} & \multicolumn{3}{|c|}{354 pts $(82.0 \%)$} & \multicolumn{3}{|c|}{4 pts $(0.9 \%)$} \\
\hline & & Countries & \multicolumn{3}{|c|}{0} & \multicolumn{3}{|c|}{2} & \multicolumn{3}{|c|}{1} & \multicolumn{3}{|c|}{14} & \multicolumn{3}{|c|}{2} \\
\hline
\end{tabular}

*China accounts for $16.2 \%$ of all medals won in London and $70.7 \%$ of all medals won by Asian nations.

The fact that 39 African nations were present at the London Paralympic Games would appear to show that the development of summer Paralympic sport in Africa has improved 
dramatically over the last 15 or so years, increasing from 16 nations in Atlanta 1996. However, a closer examination of the figures shows that of the 39 African nations in London, 31 had team sizes of less than five athletes, with 15 only sending one athlete - usually a male. Table 5 further demonstrates the domination of Europe at the Paralympic Games in terms of medal success. Using 3 points for gold, 2 points for silver, 1 point for bronze, the European share of medal success in London was 48 percent rising to 82 percent for the winter Games in Sochi 2014, whilst African success was 7.4 percent and 0 percent respectively.

This degree of asymmetry is damaging in the longer term to a movement predicated on international representation. Supporting individual athletes and teams from resource-poor regions emerges as part of that process. So too, however, is IPC's engagement in wider disability sport-based interventions. It was in response to these needs that the IPC launched the Agitos Foundation. According to former IPC development manager, Amy Farkas, the IPC has been carrying out development work in Africa since at least 2003 and works closely with the African Sports Confederation of Disabled, described in the 2003 IPC newsletter, The Paralympian, as the IPC's African regional committee. ${ }^{47}$ The IPC has certainly been running workshops in Africa covering various topics such as classification seminars for doctors and physiotherapists since around the year $2000 .{ }^{48}$ More recently, as the IPC has grown in stature and relative financial security, this process has allowed them to set up an embryonic version of the IOC's "Olympic Solidarity" to try to promote the development of sport for people with disabilities around the world. In this sense, Agitos seeks to do so by increasing awareness, forming partnerships, and securing the necessary resources to implement programmes covering four key areas: 
1. Sports development: Increase the number of people with an impairment practicing physical activity and sport.

2. Awareness and education: Raise awareness and educate people on the abilities and achievements of athletes helping to change society's attitude towards people with an impairment.

3. Advocacy and inclusion: Contribute to the implementation of the UN Convention on the Rights of Persons with Disabilities to achieve inclusion.

4. Knowledge and research: Share existing best practice and implement programmes that widen the knowledge base of the benefits of sport for people with an impairment. $^{49}$

In 2014, in the second year of its grant support programme, the Agitos Foundation put out a call for proposals from IPC member organisations to access $€ 650,000$ of funding to instigate partnerships to implement development projects that support the IPC strategic priorities - examples of projects given in Table 2. The figure available for 2015 applications has risen to $€ 1,100,000$. The priorities for 2014 fell under two areas: "National Paralympic Committees" and "Regional Organisations; and International Federations and International Organisations of Sport for the Disabled". For "National Paralympic Committees" and "Regional Organisations", the priorities included Paralympic movement awareness, athlete education, athlete development, sport technical education - coaches, classifiers, and technical officials - capacity building and leadership, and national classification strategies. For international federations and international organisations of sport for the disabled, the priorities were educational tools - coaches, classifiers, and technical officials - certification of 
international technical officials and international classifiers, organisation of youth or development competitions, equipment, and classification research.

Of the 28 successful projects in 2014 , from 76 applications, five awards went to projects specifically targeting African nations. The African Paralympic Committee received support for athlete development in advance of the 2015 All African Games. Funds for the Benin Paralympic Committee helped widen the reach of the Paralympic movement nationally. The Democratic Republic of Congo Paralympic Committee acquired assistance as part of efforts to strengthen the technical and administrative capacity in Central Africa. Ghana's Paralympic Committee was to help stage a national para-sports festival; and the Rwanda Paralympic Committee was provided with funds to enhance the athlete development pathway in view of the 2016 Paralympic games in Rio and 2020 Games in Tokyo. ${ }^{50}$

In summary, the Agitos Foundation has in a short time-frame and with little resourcing emerged as a key actor in promoting the idea of disability sport contributing to enhanced quality of life through physical activity whilst crucially linking them to the objective of increasing access to elite disability sport. Admittedly, erasing the systemic inequity in access to the technology and training necessary to produce Paralympians cannot occur in the short term. The message, however, is that the movement is committed to addressing these inequities. These are important statements of intent from a sports movement still in its formative years. It is also significant diplomatically for a movement founded on its role as an international advocate for disability rights.

The IPC is an organisation primarily concerned with promoting international elite sport for people with disabilities. Nevertheless, to enhance its profile internationally and fulfil its commitment as advocate for the rights of people with disabilities, it draws toward a wider 
agenda of representation that by definition leads to its involvement in the diplomatic process. These are two connected roles, as demonstrated, for example, through the Agitos Foundation that as an emerging NGO seeks to promote positive social and cultural change relating to disability alongside athlete development as aspects of its programmes. Promoting the rights of people with disabilities in resource-poor regions is critical to longer-term representation of countries within these regions in the Paralympic Games. It in turn forms part of the development of the Paralympics as a global brand. Engagement with ideas relating to so-called public diplomacy provide valuable insights into the development of the IPC and other organisations across the Paralympic movement as actors in international society. Traditional interpretations of public diplomacy considered relationship building and image development from the perspective of the state; and where NGOs were concerned, only insofar as their activities promoted wider state interests and representation, for instance USAID perceptions of NGOs and their role in public diplomacy articulated through a number of reports on the topic. ${ }^{51}$ However, there is increasing recognition of the central role of non-state actors in the wider public diplomacy process - say, Hocking's co-operative network model of public diplomacy that explores the significance of multi-stakeholder activity. ${ }^{52}$ Indeed, in this special edition, Pamment explores the evolution of multi-stakeholder activity from the perspective of a more participatory model of diplomacy where the pursuit of the goals of a range of stakeholders becomes part of the diplomatic process. In these senses, then, the activities of the IPC and related agencies, in particular, the Agitos Foundation, constitute exercises in emerging forms of public diplomacy.

Exploring the linkage between disability rights and the mainstreaming of disability sport is an important part of this investigation. As disability rights - forming part of the wider 
human rights agenda - have been elevated within domestic and international political discourse, they have acted as a catalyst for the mainstreaming of disability sport. At the same time, disability sports organisations, in particular the IPC and NPCs, have demonstrated that they have agency in varying degrees in promoting these wider political changes. Whilst primarily lobbying to promote their respective sporting agendas, they are also advocacy bodies, actively engaged with the disability rights agenda at the domestic, regional, and international level.

Finally, the rapid development of the Paralympic Games in scale and complexity has created a number of challenges for the Paralympic movement and, in some respects, have implications for related diplomatic discourse. For example, the right of people with intellectual disabilities to compete is likely to feature in debate concerning the future contours of the Games, since attempts by the IPC to develop its status as a disability advocacy organisation is dependent upon its capacity to provide an inclusive competitive experience. By including intellectually disabled athletes, it enhances the capacity of the Paralympic movement to develop its advocacy role. The re-introduction of athletes with an intellectual disability in three sports in 2012, changing the dynamics of the Games, is significant in this respect. Nevertheless, the complexity of classifying intellectual disability remains a major challenge for Paralympic sports that ultimately have responsibility for the development of relevant classification systems. At the same time, the Paralympic movement is working to develop their relationship with the separate global grass-roots organisation, the Special Olympics, solely focused on developing recreational and competitive sporting opportunities for people with intellectual disabilities. Meanwhile the Special Olympics movement is developing its own profile, and there are signs 
of increased recognition beyond the sports community of the capacity of the movement to contribute to public diplomacy discourse.

The expansion of Paralympic sport and the relationship between the Paralympic movement and broader concerns with the rights of people with disabilities, then, is propelling the IPC and associated organisations as advocates and administrators toward an increasingly challenging position within the international arena. Developing the Paralympic brand internationally requires mediation between these two potentially conflicting preoccupations. Ultimately, however, they are not mutually exclusive. For the IPC to become in every sense an internationally representative sporting body, it will be required to influence international discourses concerning the rights of people with disabilities on and off the sporting field. The language and techniques of public diplomacy can help promote an understanding of the dynamics of these processes.

Notes

1 Ian Brittain, From Stoke Mandeville to Sochi: A History of the Summer and Winter Paralympic Games (Champaign, IL, 2014).

2 IPC Handbook, Chapter 1.2: "Paralympic vision and mission" (April 2003): http://www.paralympic.org/the-ipc/handbook.

${ }^{3}$ James Der Derian, On Diplomacy: A Genealogy of Western Estrangement (London, 1987); Andrew Cooper, John English, and Ramesh Thakur, eds., Enhancing Global Governance: Towards a New Diplomacy? (Tokyo, 2002); Richard Langhorne, “The Diplomacy of Non-State Actors", Diplomacy and Statecraft, 16/2(2005), 331-39; David Criekemans, How Sub-national Entities Try to Develop Their Own Paradiplomacy: The Case of Flanders (1993-2005), 
Geneva: International Conference Challenges for Foreign Ministries - Managing Diplomatic Networks and Optimising Value (2006): http://www.diplomacy.edu/Conferences/MFA/papers Icriekemans.pdf; Jan Melissen, The New Public Diplomacy: Soft Power in International Relations (Basingstoke, 2006); idem., Beyond the New Public Diplomacy, Clingendael Paper No. 3 (The Hague, 2011): $\quad$ http://www.clingendael.nl/sites/default/files/ 20111014_cdsp_paper__jmelissen.pdf; Rogier van der Pluijm, "City Diplomacy: The Expanding Role of Cities in International Politics" (The Hague, 2007): http://www.uclg.org/sites/default/files/20070400_cdsp_paper_pluijm.pdf; Joseph Nye, The Future of Power (NY, 2011).

${ }^{4}$ Geoffrey Pigman and J. Simon Rofe, "Sport and Diplomacy: an introduction", Sport in Society, 17/9(2014), 1095-97.

${ }^{5}$ Stuart Murray, "Two Halves of Sports-Diplomacy”, Diplomacy \& Statecraft, 23/3(2012), 576-92; Geoffrey A. Pigman, "International Sport and Diplomacy's Public Dimension: Governments, Sporting Federations and the Global Audience", Diplomacy \& Statecraft, 25/1(2014), 94-114; Simon Rofe, "It is a squad Game: Manchester United as a diplomatic nonstate actor in international affairs", Sport and Society, 17/9(2014), 1136-54.

${ }^{6}$ Richard Espy, The Politics of the Olympic Games (Berkeley, CA, 1979); David Kanin, “The Olympic Boycott in Diplomatic Context”, Journal of Sport and Social Issues, 4/1(1980), 1-24; David Kanin, A Political History of the Olympic Games (Boulder, CO, 1981); Baruch Hazan, Olympic Sports and the Propaganda Games (New Brunswick, NJ, 1982); John Hoberman, The Olympic Crisis (NY, 1986); Alan Guttmann, The Olympics: A History of the Modern Games (Champaign, IL, 1992); Lincoln Allison, ed., The Changing Politics of Sport (Manchester, 1993); Christopher Hill, Olympic Politics: Athens to Atlanta, 2nd ed. (Manchester, 1996). 
${ }^{7}$ Lincoln Allison, The Global Politics of Sport: The Role of Global Institutions in Sport (London, 2005); Jacques Rogge, Keynote speech "The Potential of Sport in the Search for Peace and Development", International Forum on Sport, Peace and Development (7 May 2009): $\quad$ http://www.olympic.org/en/content/Olympism-in-Action/Peace-throughsport/International-Forum-on-Sport-Peace-and-Development/; Aaron Beacom, International Diplomacy and the Olympic Movement: The New Mediators (Basingstoke, 2012).

${ }^{8}$ Brian Hocking, "Multistakeholder Diplomacy: Forms, Functions, and Frustrations”, in Jovan Kurbalija and Valentin Katrandjiev, eds., Multistakeholder Diplomacy: Challenges and Opportunities (Malta, Geneva, 2006), 13-29.

${ }^{9}$ Brian Hocking, Jan Melissen, Shaun Riordan, and Paul Sharp, "Futures for Diplomacy: Integrative Diplomacy in the 21st Century", Netherlands Institute of International Relations “Clingendael”, Report 1(The Hague, 2012).

10 Scope, "DIY campaigns toolkit, step 4". (nd): http://www.scope.org.uk/campaigns/ community/diy-toolkit/step-4.

${ }^{11}$ Philip N. Howard and Malcolm R. Parks, "Social Media and Political Change: Capacity, Constraint, and Consequence", Journal of Communication, 62/2(2012), 359-62.

${ }^{12}$ Brian Hocking, "Reconfiguring public diplomacy: from competition to collaboration" in Foreign and Commonwealth Office, Engagement: Public Diplomacy in a Globalised World (London, 2008), 63-75: http://www.clingendael.nl/sites/default/files/20080700_cdsp_chapter_ hocking.pdf .

13 IPC, "IPC publishes Sochi 2014 social media guidelines" (14 September 2013): http://www.paralympic.org/news/ipc-publishes-sochi-2014-social-media-guidelines. 
${ }^{14}$ Mark Leonard, Public Diplomacy (London, 2002), 13 discusses the "paradox" of domestic issues such as civil unrest becoming in some contexts more significant in terms of diplomacy than foreign policy developments.

${ }^{15}$ Mark Leonard, with Catherine Stead, Conrad Smewing, Public Diplomacy (London, 2002): http://fpc.org.uk/fsblob/35.pdf; Melissen, New Public Diplomacy; Bruce Gregory, "American Public Diplomacy: Enduring Characteristics, Elusive Transformation”, Hague Journal of Diplomacy, 6/3/4(2011), 351-72, in Melissen, Beyond the New Public Diplomacy.

${ }^{16}$ Written evidence to House of Commons Select Committee, "FCO Public Diplomacy: 2012 Olympics" November 2010):

http://www.publications.parliament.uk/pa/cm201011/cmselect Icmfaff/writev/olympics/oly03.htm.

${ }^{17}$ House of Commons Foreign Affairs Committee, "FCO Public Diplomacy: The Olympic and Paralympic Games 2012. Second Report of Session 2010-11" (6 February 2011), 34: http://www.publications.parliament.uk/pa/cm201011/cmselect/cmfaff/581/581.pdf.

${ }^{18}$ Peter Horton and Kristine Toohey. "It comes with the Territory: terrorism and the Paralympics", in Keith Gilbert and Otto J. Schantz, eds., The Paralympic Games: Empowerment or sideshow? (Maidenhead, 2008), 190-98.

${ }^{19}$ Ibid., 195.

20 Ian Brittain, "Paralympic success as a measure of national social and economic development", International Journal of Eastern Sport and Physical Education, 4/1(2006), 3847.

21 “Iranian President to Attend Paralympics Opening Ceremony", People's Daily (2 September 2008): http://en.people.cn/90001/90776/90883/6490929.html. 
22 "Chinese President meets Iranian Counterpart", Xinhua, (6 September 2009): http://news.xinhuanet.com/english/2008-09/06/content_9806940.htm.

23 "China Signs UN Accord on Disability Rights", China Daily (31 March 2007): http://www.chinadaily.com.cn/china/2007-03/31/content 840971.htm.

24 "China Marks Help-The Disabled Day", Cri (31 March 2007): http://english.cri.cn /2946/2007/05/20/65@229167.htm..

${ }^{25}$ IPC, "Opening Ceremony to kick-off the Shooting World Championships" (14 July 2010): http://www.paralympic.org/Media_Centre/News/Sport_News/2010_07_14_a.html.

${ }^{26}$ Ian Brittain, "South Africa, Apartheid and the Paralympic Games", Sport in Society, 14/9(2011), 1167-83.

${ }^{27}$ Charles Little, "The Paralympic Protest Paradox: The Politics of Rhodesian Participation in the Paralympic Games 1960-1980", in Robert K. Barney, Michael K. Heine, Kevin B. Wamsley, and Gordon H. MacDonald, eds. Pathways: Critiques and Discourse in Olympic Research, Ninth International Symposium for Olympic Research (London, ON, 2008), 123-31. 28 "Minister and Mayor face angry hecklers over cuts and Atos", DisabledGoNews (October 2011): http://www.disabledgo.com/blog/2011/10/minister-and-mayor-face-angry-hecklers-over -cuts-and-atos/.

${ }^{29}$ Alan Roulstone "The Paralympic Legacy - A New Dawn or a False Dawn for Disabled People?", Policy Press (5 September 2012): https://policypress.wordpress.com/2012/09/05/theparalympic-legacy-a-new-dawn-or-a-false-dawn-for-disabled-people/. 30 "Ceremony for Launch of Sochi Paralympic Logo" (12 December 2009): http://02varvara.wordpress.com/2009/12/12/sochi-2014-launches-new-paralympic-gamesemblem-on-russias-first-ever-international-paralympic-winter-day/. 
${ }^{31}$ IPC News Release "UN General Assembly Adopts Truce Resolution” (21 October 2009): http://www.paralympic.org/Media_Centre/News/General_News/2009_10_21_a.html.

32 "Paralympic Games: Disabled threaten boycott over human Wrongs", Telegraph (16 July 2001): $\quad$ http://www.telegraph.co.uk/sport/3009026/Paralympic-Games-Disabled-threatenboycott-over-human-wrongs.html.

33 Disability Now (October 2008): http://www.disabiltynow.org.uk/latest-news2/world view/beijing the paralympic_legacy.

34 IOC, "IOC becomes UN observer" (19 October 2009): http://www.olympic.org/ content/news/media-resources/manual-news/1999-2009/20091/10/17/_ioc-becomes-unobserver-l.

${ }^{35}$ DFID, Reducing poverty by tackling social exclusion (London, 2005).

${ }^{36}$ Gary L. Albrecht, The Disability Business (London, 1992).

37 Cameron Crawford, "A view from the sidelines: Disability, poverty, and recreation in Canada", Journal of Leisurability, 16/2(1989), 3-9.

38 Handicap International, "Position Statement - Disability and PRS in Liberia" (nd): http://www.handicap-international.fr/...handicap/4PolitiqueHandicap/.../Position_paper_liberia. doc.

39 Rachael Reilly, "Disabilities among refugees and conflict-affected populations" (2010): http://www.fmreview.org/disability-and-displacement/rachael-reilly.html.

40 UN, "Factsheet on Persons with Disabilities", nd: http://www.un.org/disabilities/default.asp?id +18.

${ }^{41}$ Roger Levermore and Aaron Beacom, eds., Sport and International Relations (Basingstoke, 2012). 
${ }^{42}$ IPC Press Release, "All African Games Has the Potential to Create Significant Change" (21 October 2010): http://www.paralympic.org/press-release/all-african-games-have-potentialcreate-significant-change.

${ }^{43}$ IPC News Bulletin, "NPC Rwanda Celebrates International Disability Day” (2 March 2011): http://www.paralympic.org/news/npc-rwanda-celebrates-international-disability-day.

${ }^{44}$ Ian Brittain The Paralympic Games Explained, second edition (London, 2016).

${ }^{45}$ Ibid.

${ }^{46}$ Ibid.

${ }^{47}$ Email to Ian Brittain, 22 May 2015; A. Burchell, "Africa Pleads More Participation of Women in Sport and Recreation”, Paralympian, 3(2003), 10.

48 “Disability Sport Gains Ground in African Region”, Ibid., 4(2004), 8.

49 IPC, “Agitos Foundation Brochure" (2015): http://www.paralympic.org/sites/default/files/ document/120817161051631_Brochure\%2B-\%2Bfinal_1.pdf.

${ }^{50}$ Gary Anderson, "Agitos Foundation to dole out $€ 650,000$ to 28 projects through Grant Support Programme" (23 July 2014): http://www.insidethegames.biz/paralympics/1021464agitos-foundation-to-dole-out-650-000-to-28-projects-through-grant-support-programme.

${ }^{51}$ Nadia Naviwala [report prepared for USAID Afghanistan/Pakistan Task Force], "Harnessing Local Capacity: US assistance and NGOs in Pakistan" (2010): http://pdf. usaid.gov/pdf_docs/pnaea519.pdf..

${ }^{52}$ Hocking, "Multistakeholder diplomacy". 